\title{
Association between eating habits, body mass index, cardiorespiratory fitness, and cardiometabolic risk factors in children
}

\author{
Associação entre os hábitos alimentares, indice \\ de massa corporal, aptidão cardiorrespiratória \\ e fatores de risco cardiometabólico em crianças
}

\author{
Miguel Angelo dos Santos DUARTE JUNIOR ${ }^{1}$ (iD) 0000-0002-6367-557X \\ Adroaldo Cezar Araujo GAYA1 ID 0000-0002-5941-5089 \\ Vanilson Batista LEMES1 (ID) 0000-0003-3298-4449 \\ Camila Felin FOCHESATTO ${ }^{1}$ iD 0000-0002-8777-074X \\ Caroline BRAND² ID) 0000-0002-5624-3592 \\ Anelise Reis GAYA 1 ID 0000-0002-8335-6947
}

A B S T R A C T

\section{Objective}

To verify the multivariate relationships between eating habits, cardiorespiratory fitness, body mass index, and cardiometabolic risk factors in children.

\section{Methods}

This is a cross-sectional study developed in a public elementary school with 60 first- to sixth-graders. Their eating habits were assessed using the Food Frequency Survey, weight, height, and cardiorespiratory fitness, assessed according to

\footnotetext{
1 Universidade Federal do Rio Grande do Sul, Escola de Educação Física, Fisioterapia e Dança, Programa de Pós-Graduação em Ciências do Movimento Humano. R. Felizardo, n. 750, Jardim Botânico, 90690-200, Porto Alegre, RS, Brasil. Correspondence to: AG GAYA. E-mail: <anegaya@gmail.com>.

2 Universidade de Santa Cruz do Sul, Departamento de Educação Física e Saúde, Programa de Pós-Graduação em Promoção da Saúde. Santa Cruz do Sul, RS, Brasil.

Support: Conselho Nacional de Desenvolvimento Científico e Tecnológico (CNPq, National Council for Scientific and Technological Development) (Process n. 401969/2016-9); Coordenação de Aperfeiçoamento de Pessoal de Nivel Superior (CAPES, Coordination for the Improvement of Higher Education Personnel).

Article elaborated from the dissertation by MAS DUARTE JUNIOR, entitled "A associação dos hábitos alimentares e aptidão cardiorrespiratória com o estado nutricional e risco cardiovascular em crianças”. Universidade Federal do Rio Grande do Sul, 2019.
}

How to cite this article

Duarte Junior MAS, Gaya ACA, Lemes VB, Fochesatto CF, Brand C, Gaya AR. Association between eating habits, body mass index, cardiorespiratory fitness, and cardiometabolic risk factors in children. Rev Nutr. 2021;34:e200116. https://doi.org/10.1590/1678-9 $865202134 \mathrm{e} 200116$ 
the Projeto Esporte Brasil protocol. Moreover, the variables, high-density lipoprotein, low-density lipoprotein, glucose, insulin, C-reactive protein, adiponectin, leptin, diastolic and systolic blood pressure were evaluated. Descriptive statistics were used for data analysis and generalized estimation equations were used for the analysis of direct and indirect relations, in a multivariate analysis model with several simultaneous outcomes.

\section{Results}

It appears that the eating habits and cardiorespiratory fitness explain $20 \%$ of the body mass index. Cardiometabolic risk factors are explained by the relationship between eating habits, cardiorespiratory fitness, and body mass index, according to the following percentages: 29\% (systolic blood pressure), 18\% (diastolic blood pressure), 63\% (leptin), 4\% (adiponectin), 14\% (C-reactive protein), 17\% (insulin), 10\% (high-density lipoprotein), 1\% (low-density lipoprotein), $4 \%$ (glucose). It is also observed that the effects of the eating habits on cardiometabolic risk factors are indirect, that is, they are dependent on changes in the body mass index and cardiorespiratory fitness levels.

\section{Conclusion}

The relationship between eating habits and cardiometabolic risk factors in children is dependent on cardiorespiratory fitness and body mass index. Thus, our findings suggest a multivariate relationship between these factors.

Keywords: Cardiovascular diseases. Cardiorespiratory fitness. Children. Feeding behavior.

\section{R E S U M O}

\section{Objetivo}

Verificar as relações multivariadas entre hábitos alimentares, aptidão cardiorrespiratória, índice de massa corporal e fatores de risco cardiometabólico em crianças.

\section{Métodos}

Trata-se de um estudo de corte transversal, desenvolvido com 60 crianças em uma escola pública, de ensino fundamental. Os hábitos alimentares foram avaliados por meio do Inquérito de Frequência Alimentar, peso, estatura e aptidão cardiorrespiratória, avaliados de acordo com o protocolo do Projeto Esporte Brasil. Ainda, foram avaliadas as variáveis lipoproteína de alta densidade, lipoproteína de baixa densidade, glicose, insulina, proteína C-reativa, adiponectina, leptina, pressão arterial diastólica e sistólica. Para a análise de dados, utilizou-se estatística descritiva e, para a análise das relações diretas e indiretas, equações de estimativa generalizadas, em uma modelagem de análise multivariada com diversos desfechos simultâneos.

\section{Resultados}

Verifica-se que os hábitos alimentares e a aptidão cardiorrespiratória explicam o índice de massa corporal em $20 \%$. Os fatores de risco cardiometabólico são explicados pelas relações entre hábitos alimentares, aptidão cardiorrespiratória e índice de massa corporal, de acordo com os seguintes percentuais: 29\% (pressão arterial sistólica), 18\% (pressão arterial diastólica), 63\% (leptina), 4\% (adiponectina), 14\% (proteína C-reativa), 17\% (insulina), 10\% (lipoproteína de alta densidade), 1\% (lipoproteína de baixa densidade), 4\% (glicose). Ainda, observa-se que os efeitos dos hábitos alimentares nos fatores de risco cardiometabólico são indiretos, isso é, são dependentes das alterações no índice de massa corporal e nos níveis aptidão cardiorrespiratória.

\section{Conclusão}

A relação entre os hábitos alimentares e os fatores de risco cardiometabólico em crianças é dependente da aptidão cardiorrespiratória e do índice de massa corporal, de forma que os achados deste estudo sugerem uma relação multivariada entre esses fatores.

Palavras-chave: Doenças cardiovasculares. Aptidão cardiorrespiratória. Crianças. Comportamento alimentar.

\section{NTRODUCTION}

Obesity is a chronic disease with a multifactorial clinical condition - heredity, inadequate diets, and low levels of physical activity are all risk factors for it [1]. Additionally, it is the main cause of childhood and teenage non-transmissible chronic diseases, such as diabetes, hypertension, and dyslipidemias [2-5]. 
The relationship between nutritional states and metabolic risks in children and teenagers is well established in the literature. Several studies associate higher values of the Body Mass Index (BMI) with increased levels of triglycerides and fasting glycaemia, as well as with the reduction of High-Density Lipoprotein Cholesterol (HDL-C) [6-8]. Thus, evaluating the BMI allows monitoring the nutritional state in a simple and operational way, also granting important information for health assessments in the school.

In this context, the nutritional state is directly influenced by dietary habits [9]. For instance, obese kids usually have characteristic diets, with great intakes of sodium, fat, and sugar, but poor in fruits, vegetables, and fibers $[9,10]$. However, the relation between eating habits and chronic diseases is still uncertain, especially for children and teenagers. The ways in which unhealthy diets influence children's biochemical parameters like inflammatory cytokines, C-Reactive Protein (CRP), adiponectin, triglycerides, total cholesterol, glucose, and insulin, remain unclear $[11,12]$.

Monitoring eating habits and evaluating the BMI are not only important for diagnosing obesity and overweight. Cardiorespiratory Fitness (CRF) is one of the most important health predictors in children and teenagers $[13,14]$. Studies show that lower CRF levels are linked with cardiovascular risk and metabolic syndrome $[9,15,16]$. Some authors suggest that CRF is connected with the nutritional state in children of school age, meaning that good CRF levels are associated with adequate BMI values [17-19]. Also, the literature has shown that CRF might influence the relation between obesity and cardiovascular risk [20-22].

Thus, research has been concerned with the proper ways of interpreting the relationship between obesogenic behaviors, no longer in an individual fashion, but centering the effects of their interactions in kids' cardiometabolic risk factors [22]. The authors suggest that the eating habits, the CRF levels, and the nutritional state are related in an unclear way and that the conjunction of these behaviors might support a connection between eating habits, obesity and overweight, and the early risk of developing several cardiometabolic factors $[23,24]$.

The literature has presented associations between eating habits and inflammatory states in children and teenagers $[1,12,20]$. Improved CRF and physical and muscular fitness, opposingly, result in better levels of inflammatory markers $[6,12,14]$. It should be noted that the adipose tissue is no longer seen as solely energy storage and is now considered an endocrine organ which expels different metabolites with different functions. Therefore, different dietary patterns, nutritional states, and CRF seem to influence the inflammatory states of children and teenagers [12].

Consistent evidence of the relations between eating habits, BMI, CRF, and the cardiovascular and cardiometabolic risk factors during childhood is definitely lacking. This gap in the literature is the main justification for the present study. Our working hypothesis is that the BMI and the cardiometabolic risk factors are directly related, and that the eating habits, CRF, BMI, and cardiometabolic risks are indirectly related. The goal of this study, then, is to verify the multivariate relations between eating habits, CRF, BMI, and cardiometabolic risk factors in children.

\section{METHODS}

The cross-sectional quantitative study was carried out in a public school in Porto Alegre, Brazil. The population included all first- to fifth-graders in the school $(n=480)$. All the students that completed the assessments (anthropometric, eating habits, blood, blood pressure, and CRF) were included. The convenience sample was composed of 60 students ( 27 boys and 33 girls) with ages between six and eleven. All the evaluations happened after the approval of the Human Research Ethics Committee of the Universidade 
Federal do Rio Grande do Sul (UFRGS, Federal University of Rio Grande do Sul), under the process number 2.571.198, and with free informed consent terms signed by both the children and their legal guardians.

The sample was calculated a posteriori using the software G*Power version 3.1 [25] for the analyses of the association between eating habits and CRF with the BMI, in multivariate analyses with more than one endpoint measure. We also considered the effect size $\mathrm{f}^{2}=0,15$ (small/medium), the significance level of 0.05 , for $n=60$ and the five predictors involved, resulting in a power of test of $1-\beta=0,80$ [26].

The eating habits were evaluated using the Food Frequency Survey of the National System of Food and Nutrition Security (SISVAN, Sistema Nacional de Segurança Alimentar e Nutricional) [27]. The questionnaire aims to identify healthy and unhealthy dietary habits using indicators of food consumption and comparing them with the Dietary Guidelines for the Brazilian Population [28]. It considers markers of healthy eating practices (beans, vegetables, fresh leaves and fruit) and unhealthy ones (fried snacks, candies and treats, soda, ultra-processed salty foods). The consumption is classified as frequent when it happens more than five times a week, and unusual or not frequent for less than five times a week. That interpretation is in accordance with the Pesquisa Nacional de Saúde do Escolar (PeNSE, National Research on School Children's Health), on which the consumption of eating markers is presented in means and frequencies [29].

The Food Frequency Survey (SISVAN) was applied by trained nutritionists with individualized and previously scheduled dates and times, on which the kids and their parents were present. After the data collection, we created a score of eating habits where both the frequent consumption of each marker of healthy habits and the infrequent consumption of each marker of unhealthy habits amounted one point. Each child could obtain a maximum of seven points in this score.

The anthropometric and CRF evaluations happened in the school and were carried out by trained researchers in a date previously scheduled and following the protocols of the Projeto Esporte Brasil (PROESP-BR, Project Sports Brazil) [30]. For the anthropometric measures, the kids were oriented to come barefooted and wearing light clothing. An anthropometric scale with a precision of 500 grams was used to determine the body mass, and the height was determined with a measuring tape. Afterwards, the BMI was calculated with the following formula: BMl=weight/height ${ }^{2}\left(\mathrm{Kg} / \mathrm{m}^{2}\right)$ [29]. The BMl was classified by age in a Z-score, in accordance with the World Health Organization (WHO) and this classification was the basis for the calculation of the overweight or obesity frequency [31].

The CRF was assessed with the six-minute run/walk test, according to PROESP-BR, and was executed by a team of trained evaluators [30]. During the test, students were organized in small groups which were positioned in a multi-sports court and oriented to go round the court as many times as possible during the six minutes. At the end, the distances travelled were registered in meters [30].

To determine the cardiometabolic risk factors, blood from the participants was drawn and analyzed. The evaluation happened in the research laboratory of the Escola de Educação Física, Fisioterapia e Dança (ESEFID/UFRGS, School of Physical Education, Physiotherapy, and Dance) after a twelve-hour fasting period, with disposable material, and in the presence of the child's parents or legal guardians. The blood samples were centrifuged and plasma and serum were aliquoted and frozen to $-80^{\circ} \mathrm{C}$ until the analysis. The concentrations of HDL-C and glucose were analyzed with the automatic colorimetric method (Cobas C111, Roche, Basel, Switzerland). The Low-Density Lipoprotein (LDL-C) was determined by the equation proposed by Friedewald et al. [32]. The concentrations of insulin, leptin, adiponectin, and CRP were determined by ELISA using commercial kits (DRG International, Springfield, USA and Abcam, Cambridge, UK).

The evaluation of Systolic (SBP) and Diastolic Blood Pressures (DBP) happened previously to the blood collection and was performed with an automatic monitor of blood pressure (Omron Digital Hem-7130), with different armbands according to the circumference of the child's right arm. Children had to be seated 
for at least five minutes and have their arms in a resting position. The first and second measurements were made after 5 and 10 minutes resting. The means of these two measurements was used for the data analysis.

For the analysis of the descriptive data, we first performed a visual inspection using histograms of normality curves, dispersion diagrams, histograms, and Kolmogorov-Smirnov tests. An independent $t$-test was carried out to describe possible previous differences between the sexes in all continuous variables. We also considered the means and standard deviation for age, body mass, height, BMI, CRF, eating habits' score, systolic blood pressure, diastolic blood pressure, adiponectin, CRP, insulin HDL-C, LDL-C, and glucose.

To verify the possible associations between the BMI, CRF, eating habits, and cardiometabolic risk factors, the models were adjusted for sex and age, and the direct and indirect relations were analyzed using generalized estimating equations, in a modeling of multivariate analysis with more than one endpoint measure. We considered the smallest values of Akaike and Bayesian Information Secuteron in Bayesian parameters as indicators of the best model. The final results of this analysis were expressed accordingly to a pathways diagram (MUNROS) [33]. All the analysis were carried out with the software IBM SPSS [34], AMOS, and Excel, considering an alpha of $5 \%$.

\section{R E S U L T S}

The descriptive categories are presented by sex in Table 1. It is noteworthy that boys present higher average values of HDL-C $(p=0.04)$ and adiponectin $(p=0.04)$ compared to girls. As to their eating habits, the average score was $4.05( \pm 1.5)$ in the maximum scale of 7 points. For the markers of healthy eating, we identified a high consumption of fruits in $61.0 \%$ of the children, vegetables in $59.5 \%$, and beans in $71.3 \%$. For the markers of unhealthy eating, $48.3 \%$ of the children often had ultra-processed foods, $41.3 \%$ usually had soda, $69.2 \%$ candies, and $14.5 \%$ fried snacks.

Table 1. Characterization of the sample according to sex. Porto Alegre, Brasil, 2019.

\begin{tabular}{|c|c|c|c|c|c|c|c|}
\hline & \multicolumn{2}{|c|}{ Male $(n=27)$} & \multicolumn{2}{|c|}{ Female $(n=33)$} & \multirow[b]{2}{*}{$\mathrm{T}$} & \multirow[b]{2}{*}{ DF } & \multirow[b]{2}{*}{$p$} \\
\hline & Means & SD & Means & SD & & & \\
\hline Age (years) & 9.00 & 1.35 & 8.00 & 1.41 & 0.42 & 58.0 & 0.67 \\
\hline Body mass (kg) & 36.00 & 9.57 & 37.57 & 11.93 & -0.51 & 58.0 & 0.60 \\
\hline Height (cm) & 138.00 & 8.17 & 137.00 & 10.74 & 0.39 & 58.0 & 0.69 \\
\hline \multirow[t]{2}{*}{ BMI $\left(\mathrm{kg} / \mathrm{m}^{2}\right)$} & 18.72 & 4.04 & 19.49 & 4.21 & -0.71 & 58.0 & 0.47 \\
\hline & $\mathrm{n}$ & $\%$ & $\mathrm{n}$ & $\%$ & & & \\
\hline Overweight & 3 & 11.10 & 8 & 24.20 & & & \\
\hline \multirow[t]{2}{*}{ Obesity } & 9 & 33.33 & 10 & 30.30 & & & \\
\hline & Means & SD & Means & SD & $\mathrm{T}$ & DF & $\mathrm{p}$ \\
\hline CRF $(m)$ & 799.52 & 166.74 & 737.85 & 101.34 & 1.68 & 41.0 & 0.10 \\
\hline Eating Score & 3.74 & 1.48 & 4.30 & 1.53 & -1.43 & 58.0 & 0.15 \\
\hline $\mathrm{SBP}(\mathrm{mmHg})$ & 105.48 & 14.99 & 106.12 & 11.17 & -0.18 & 58.0 & 0.85 \\
\hline $\mathrm{DBP}(\mathrm{mmHg})$ & 62.26 & 9.57 & 60.85 & 8.64 & 0.59 & 58.0 & 0.55 \\
\hline Leptin (ng/mL) & 5.02 & 7.01 & 6.58 & 7.36 & -0.83 & 58.0 & 0.40 \\
\hline Adiponectin $(\mu \mathrm{g} / \mathrm{mL})^{*}$ & 8.77 & 6.44 & 5.94 & 3.39 & 2.06 & 37.5 & 0.04 \\
\hline C-reactive Protein (mg/L) & 2.20 & 1.98 & 2.59 & 1.99 & -0.73 & 58.0 & 0.46 \\
\hline Insulin (uU/mL) & 11.30 & 5.47 & 13.77 & 9.69 & -1.17 & 58.0 & 0.24 \\
\hline $\mathrm{HDL}-\mathrm{C}(\mathrm{mg} / \mathrm{dL})^{*}$ & 47.20 & 10.84 & 40.38 & 6.50 & 2.87 & 40.6 & 0.04 \\
\hline LDL-C (mg/dL) & 87.89 & 24.15 & 86.83 & 24.03 & 0.17 & 58.0 & 0.86 \\
\hline Glucose (mg/dL) & 92.64 & 4.55 & 92.51 & 7.17 & 0.08 & 54.8 & 0.92 \\
\hline
\end{tabular}

Note: Overweight and Obesity prevalence, according to the WHO. "Sex differences (independent $t$ test; $p<0,05$ ); BMI: Body Mass Index; CRF: Cardiorespiratory Fitness; DBP: Diastolic Blood Pressure; DF: Degress of Freedom; DL-C: High-Density Lipoprotein Cholesterol; LDL-C: Low-Density Lipoprotein Cholesterol; SBP: Systolic Blood Pressure; T: Student's $t$ Test; SD: Standard Deviation. 
Figure 1 presents the total and direct relations between eating habits, CRF, BMI, and cardiometabolic risk factors. The analysis performed with a multivariate generalized linear model shows that the eating habits and CRF explain 20\% of the BMI. The cardiometabolic risk factors are explained by the relations between the eating habits, CRF, and BMl according to the following percentages: $29 \%$ (SBP), 18\% (DBP), 63\% (leptin), 4\% (adiponectin), 14\% (CRP), 17\% (insulin), 10\% (HDL-C), 1\% (LDL-C), 4\% (glucose).

However, Table 2 shows that the impact of the eating habits in cardiometabolic risk factors is indirect and dependent on the alterations in the BMI and CRF levels. That suggests a singly multivariate effect of the eating habits, BMI, and CRF in children's cardiometabolic risk factors. We also identified direct relations between the $\mathrm{BMI}$ and the cardiometabolic risk factors as SBP ( $\beta: 0.538 ; p: 0.001)$ DBP ( $\beta$ :0.429; $p: 0.002)$, leptin ( $\beta: 0.793 ; p: 0.001), \operatorname{CRP}(\beta: 0.372 ; p: 0.007)$, insulin $(\beta: 0.418 ; p: 0.001)$, and HDL-C $(\beta:-0.318 ; p: 0.006)$.

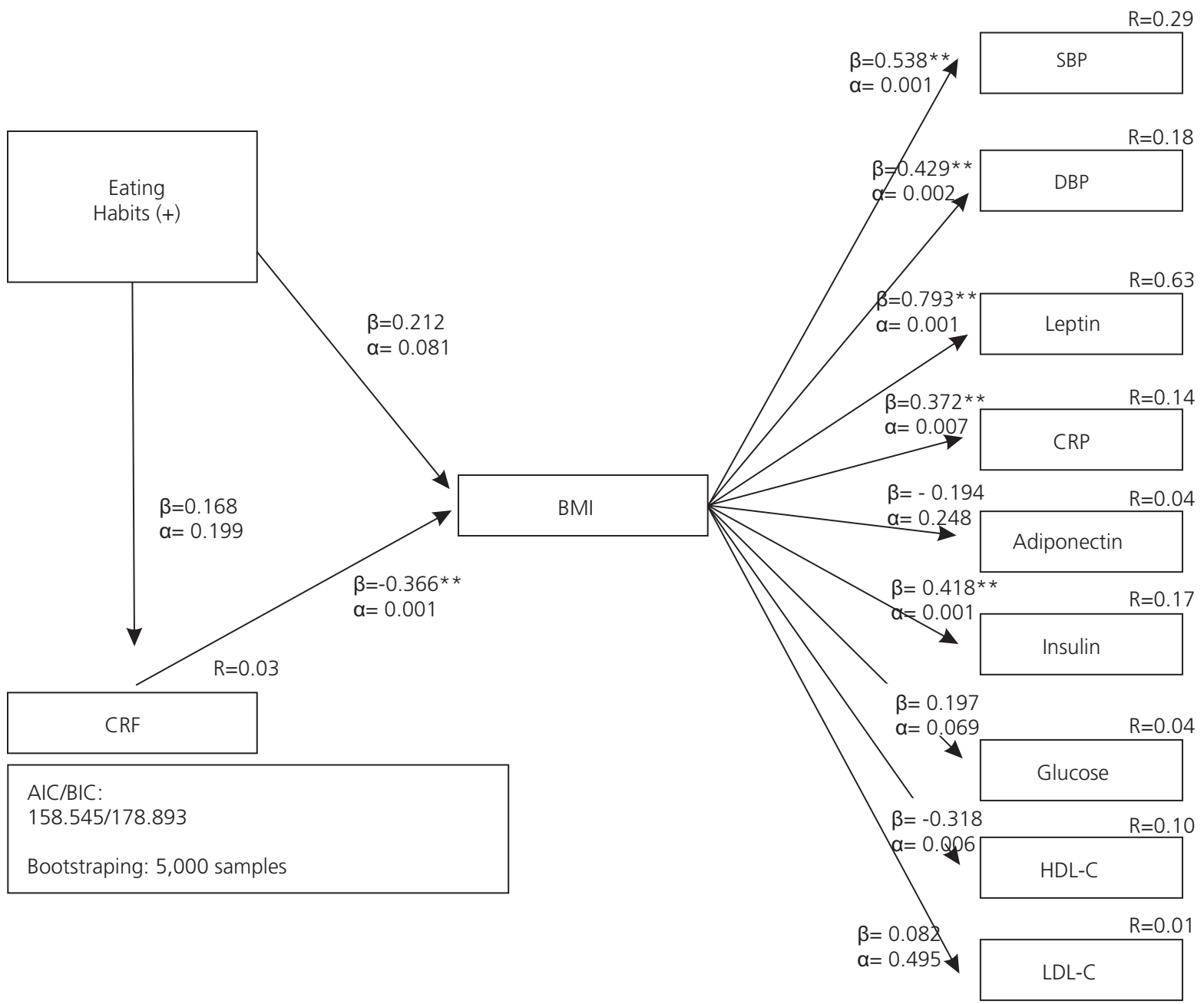

Figure 1. Relations between the eating habits and cardiometabolic risk factors mediated by the body mass index and cardiorespiratory fitness. Note: Results adjusted for age and sex; $\beta$ : Beta values standardized in Z-scores; a: Level of statistical significance, alfa below $0,05^{* *} ; \mathrm{R}$ : Squared multiple correlation level.

AIC: Akaike Information Criterion; BIC: Bayesian Information Criterion; BMI: Body Mass Index; CRF: Cardiorespiratory Fitness; CRP: C-Reactive Protein; DBP: Diastolic Blood Pressure; HDL-C: High-Density Lipoprotein Cholesterol; LDL-C: Low-Density Lipoprotein Cholesterol; SBP: Systolic Blood Pressure. 
Table 2. Direct and indirect relations between eating habits and factors for cardiometabolic risks mediated by the body mass index and cardiorespiratory fitness.

\begin{tabular}{|c|c|c|c|}
\hline \multicolumn{4}{|c|}{ Direct relations } \\
\hline & & $\beta$ & $p$ \\
\hline Eating habits & CRF & 0.168 & 0.199 \\
\hline CRF & $\mathrm{BMI}^{*}$ & -0.366 & 0.001 \\
\hline Eating habits & BMI & -0.212 & 0.081 \\
\hline \multicolumn{4}{|c|}{ Direct effects } \\
\hline \multirow{2}{*}{ Variables } & \multicolumn{2}{|c|}{ BMI } & \\
\hline & $\beta$ & $p$ & \\
\hline $\mathrm{SBP}^{*}$ & 0.538 & 0.001 & \\
\hline DBP* & 0.429 & 0.002 & \\
\hline Leptin* & 0.793 & 0.001 & \\
\hline Adiponectin & -0.194 & 0.248 & \\
\hline $\mathrm{CRP}^{*}$ & 0.372 & 0.007 & \\
\hline Insulin* & 0.418 & 0.001 & \\
\hline HDL-C* & -0.318 & 0.006 & \\
\hline LDL-C & 0.082 & 0.495 & \\
\hline \multirow[t]{2}{*}{ Glucose } & 0.197 & 0.069 & \\
\hline & \multicolumn{2}{|c|}{ Indirect effects } & \\
\hline \multirow{2}{*}{ Variables } & \multicolumn{2}{|c|}{ Eating Habits } & \\
\hline & $\beta$ & $p$ & \\
\hline $\mathrm{IMC}$ & -0.061 & 0.141 & \\
\hline LDL & -0.022 & 0.317 & \\
\hline Glucose & -0.054 & 0.065 & \\
\hline $\mathrm{HDL}^{*}$ & 0.087 & 0.026 & \\
\hline Insulin* & -0.114 & 0.016 & \\
\hline$P C R^{*}$ & -0.102 & 0.029 & \\
\hline Adiponectin & 0.053 & 0.119 & \\
\hline Leptin* & -0.217 & 0.031 & \\
\hline $\mathrm{DBP}^{*}$ & -0.117 & 0.023 & \\
\hline \multirow[t]{2}{*}{$\mathrm{SBP}^{*}$} & -0.147 & 0.023 & \\
\hline & \multicolumn{2}{|c|}{ Indirect effects } & \\
\hline \multirow{2}{*}{ Variables } & \multicolumn{2}{|c|}{ CRF } & \\
\hline & $\beta$ & $p$ & \\
\hline$\overline{\mathrm{LDL}}$ & -0.030 & 0.433 & \\
\hline Glucose* & -0.072 & 0.049 & \\
\hline $\mathrm{HDL}^{*}$ & 0.116 & 0.004 & \\
\hline Insulin* & -0.153 & 0.001 & \\
\hline$C R P^{*}$ & -0.136 & 0.004 & \\
\hline Adiponectin & 0.071 & 0.143 & \\
\hline Leptin* & -0.290 & 0.001 & \\
\hline $\mathrm{DBP}^{*}$ & -0.157 & 0.001 & \\
\hline SBP* & -0.197 & 0.001 & \\
\hline
\end{tabular}

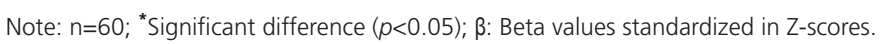

BMI: Body Mass Index; CRF: Cardiorespiratory Fitness; CRP: C-Reactive Protein; DBP: Diastolic Blood Pressure; HDL-C: High-Density Lipoprotein Cholesterol; LDL-C. Low-Density Lipoprotein Cholesterol; SBP: Systolic Blood Pressure.

\section{DISCUSSION}

The present study aimed to verify the multivariate relations between eating habits, CRF, BMI, and cardiometabolic risk factors in children. Its main results suggest that the relations between eating habits and 
risk factors were dependent on the BMI and CRF. Thus, for a positive relation with better cardiometabolic health levels, children depend on positive changes in their eating habits, reduction of the BMI values, and increased levels of CRF.

The literature broadly suggests that adequate eating habits are strictly related to a proper nutritional state $[10,35]$. Therefore, the results of this study, in which the relations of eating patterns and cardiometabolic risk factors was dependent on the BMI values, highlight the multivariate relation of those factors for the age group studied. Such results are probably explained by the indirect relations of the eating habits with the BMI and consequently, of the latter with the risk factors for cardiometabolic diseases.

In the same approach, we observe that improved CRF levels are associated with lower BMI values and contribute conjointly for a lower cardiometabolic risk in children of school age. These results are in agreement with the literature, since adequate CRF and BMI values were associated with a decreased risk for the development of cardiometabolic diseases $[6,20,22,36,37]$. Notwithstanding, the most important result in this study in relation to previous research is the difficulty in finding associations between eating habits and cardiometabolic risk factors for the early ages. The data considered in our research suggests that such an effect exists. However, it is dependent on the BMI and the CRF, highlighting the relevance of multivariate analyses for understanding these variables when aggregated. In the same sense, AgostinisSobrinho et al. [12], stress that evaluating the possible associations between cardiometabolic risk factors and muscular fitness requires considering the eating habits, which might have a confounder effect, mitigating inflammatory processes.

The CRF did not present a direct relation with the cardiometabolic risk factors. That relation depended on the BMI. In that sense, children with better CRF and lower BMI values also presented lower cardiometabolic risk. Other studies sought to clarify these relations, showing that improved CRF levels reduce cardiometabolic risk factors in children with higher BMI values. However, it is important to highlight that this occurs when the comparison examines overweight/obese children. When overweight/obese children are compared with children with adequate weights, such influence of the CRF does not hold. $[6,18,20]$.

Some authors also suggest that better CRF levels might constrict the hazards of a profile with metabolic risks, as obese and overweight children who have better CRF levels were found to have lower risks in that sense $[20,22]$. Moreover, the risk was even lower when the BMI and the physical fitness were adequate. These results support other studies that suggest that good CRF levels might work to attenuate obesity's harmful effects in children and teenagers $[21,22,38]$.

Thus, it is proven that CRF is a predictor of cardiovascular risk, metabolic syndrome, and general health $[9,16]$. As our findings show, it might also act as a mediator of the relations between eating habits, obesity, and cardiometabolic risk.

In short, eating habits and CRF explain 20\% of the BMI and are important factors in the relation with cardiometabolic risk. Besides, the eating habits, CRF, and BMI might explain $29 \%$ of the SBP values, $18 \%$ for the DBP, $63 \%$ for leptin, and $17 \%$ for insulin, and are therefore determinant in children's metabolic profile.

Thus, intervention programs that foster the adoption of better eating habits and CRF levels will also favor improved nutritional states and consequently, lower cardiometabolic risk. We stress the importance of stimulating the consumption of fresh food, fruits, vegetables, and cereals, as well as of reducing the consumption of industrialized foods, in order to achieve adequate energy balance, which is fundamental for weight control and obesity treatment $[39,40]$. Additionally, physical exercises are crucial for the improvement of CRF. In that sense, moderate-intensity physical activity, sports, and even a significative involvement in Physical Education classes are effective [13,41-44]. Thus, we highlight the importance of contributing 
with the development of physically active children who meet the recommendations of the World Health Organization of 60 minutes of moderate or vigorous physical activity every day [45].

As an innovative point, our results show that, together, the analyzed variables (CRF and eating habits) associate with overweight and obesity and that they are the main risk factors for cardiometabolic diseases and inflammatory markers since childhood. We were able to observe that behavior in a multivariate analysis pointing to the role of each variable in the relation with cardiometabolic diseases and inflammatory markers in children. Nevertheless, our study presents some limitations. Among them, we call attention to the impossibility of treating cause and effect when presenting the relation between the variables, as these variables are obtained in a transversal study. It is important to inform, though, that the sample calculation was carried out afterwards and considering only small and medium effect sizes, thus a larger number of subjects would be necessary to detect mathematically weak but clinically important associations. Nevertheless, we were very careful with the effect sizes and the relevance of each of them considering the relevance of the values in a clinical perspective.

\section{CONCLUSION}

The relation between eating habits and cardiometabolic risk factors in children is dependent on the CRF and the BMI. Therefore, the precocious stimulation of healthy lifestyles, including healthy eating habits and the regular practice of physical activity, is fundamental for good CRF levels. Adequate nutritional states and better metabolic indicators will ensue as a consequence of these behaviors. Indeed, our findings suggest a multivariate relation among those factors, indicating the importance of public health interventions and policies on all those aspects.

\section{ACKNOWLEDGMENTS}

We thank the Conselho Nacional de Desenvolvimento Científico e Tecnológico (CNPq, National Council for Scientific and Technological Development) and the Coordenação de Aperfeiçoamento de Pessoal de Nivel Superior (CAPES, Coordination for the Improvement of Higher Education Personnel (Coordenação de Aperfeiçoamento de Pessoal de Nivel Superior) for the financial support for the realization of this study.

\section{CONTRIBUTORS}

MA DUARTE JUNIOR, AR GAYA, CF FOCHESATTO, and C Brand participated in the planning of the work, research conception, data collection and analysis, and writing of the article. VB LEMES e ACA GAYA contributed with the data analysis, writing of the results, and final review of the work.

\section{REFERENCIAS}

1. Paiva ACT, Couto CC, Lemos Masson AP, Monteiro CAS, Freitas CF. Obesidade infantil: análises antropométricas, bioquímicas, alimentares e estilo de vida. Rev Cuid. 2018;9(3):2387-99. https://doi.org/10.15649/cuidarte.v9i3.575

2. Jesus GMD, Assis MAAD, Kupek E, Dias LA. Avaliação da atividade física de escolares com um questionário via internet. Rev Bras Med Esporte. 2016;22(4):261-6. https://doi.org/10.1590/1517-869220162204157067

3. Nasreddine L, Shatila H, Itani L, Hwalla N, Jomaa L, Naja, F. A traditional dietary pattern is associated with lower odds of overweight and obesity among preschool children in Lebanon: a cross-sectional study. Eur J Nutr. 2019;58(1):91-102. https://doi.org/10.1007/s00394-017-1574-0 
4. Bruscato, NM, Pitrez Filho MS, Vargas LTR, Hauschild JA, Baldisserotto M, Sanseverino R, et al. A prevalência de obesidade na infância e adolescência é maior em escolas públicas no sul do Brasil. Nutr Clin Diet Hosp. 2016;36(4):5964. https://doi.org/10.12873/364bruscato

5. Setayeshgar S, Ekwaru JP, Maximova K, Majumdar SR, Storey KE, McGavock J, et al. Dietary intake and prospective changes in cardiometabolic risk factors in children and youth. Appl Physiol Nutr Metab. 2017;42(1):39-45. https:// doi.org/10.1139/apnm-2016-0215

6. Pérez-Bey A, Segura-Jiménez V, Fernández-Santos, JDR, Esteban-Cornejo I, Gómez-Martínez S, Veiga OL, et al. The influence of cardiorespiratory fitness on clustered cardiovascular disease risk factors and the mediator role of body mass index in youth: The UP\&DOWN Study. Pediatr Diabetes. 2018;20(1):32-40. https://doi.org/10.1111/ pedi. 12800

7. Gaya AR, Brand C, Dias AF, Gaya ACA, Lemes VB, Mota J. Obesity anthropometric indicators associated with cardiometabolic risk in Portuguese children and adolescents. Prev Med Rep. 2017;8:158-62. https://doi.org/10.1016/j. pmedr.2017.10.002

8. Wheelock KM, Fufaa, GD, Nelson RG, Hanson RL, Knowler WC, Sinha M. Cardiometabolic risk profile based on body mass index in American Indian children and adolescents. Pediatr Obes. 2017;12(4):295-303. https://doi. org/10.1111/ijpo.12142

9. Liberali R, Kupek E, Assis MAAD. Dietary patterns and childhood obesity risk: a systematic review. Child Obes. 2020;16(2):70-85. https://doi.org/10.1089/chi.2019.0059

10. Calderón García A, Marrodan Serrano D, Villarino Marín A, Martínez Álvarez JR. Valoración del estado nutricional y de hábitos y preferencias alimentarias en una población infanto-juvenil (7 a 16 años) de la Comunidad de Madrid. Nutr Hosp. 2019;36(2):394-404. https://doi.org/10.20960/nh.2244

11. Rocha NP, Milagres LC, Longo GZ, Ribeiro AQ, Novaes JF. Association between dietary pattern and cardiometabolic risk in children and adolescents: a systematic review. J Pediatr. 2016;93(3):214-22. https://doi.org/10.1016/j. jped.2017.01.002

12. Agostinis-Sobrinho C, Brand C, Moreira C, Lopes L, Oliveira-Santos J, Silva P, et al. Muscular fitness, Southern European Atlantic diet and inflammation in adolescents. Azorean Physical Activity and Health Study II. Eur J Sport Sci. 2018;18(1):104-11. https://doi.org/10.1080/17461391.2017.1394368

13. Ortega FB, Cadenas-Sanchez C, Migueles JH, Labayen I, Ruiz JR, Sui X, et al. Role of physical activity and fitness in the characterization and prognosis of the metabolically healthy obesity phenotype: a systematic review and metaanalysis. Prog Cardiovasc Dis. 2018;61(2):190-205. https://doi.org/10.1016/j.pcad.2018.07.008

14. Cabanas-Sánchez V, Martínez-Gómez D, Izquierdo-Gómez R, Segura-Jiménez V, Castro-Piñero J, Veiga OL. Association between clustering of lifestyle behaviors and health-related physical fitness in youth: The UP\&DOWN Study. J Pediatr. 2018;199:41-8. https://doi.org10.1016/j.jpeds.2018.03.075

15. Andersen LB, Lauersen JB, Brond, JC, Anderssen SA, Sardinha LB, Steene-Johannessen J, et al. A new approach to define and diagnose cardiometabolic disorder in children. J Diabetes Res. 2015;2015. https://doi.org/10.1155/2015/539835

16. Á Latorre Roman P, Mora López D, García FP. Prácticas de alimentación, actividad física y condición física de niños preescolares españoles: Influencia de variables sociodemográficas. Arch Argent Pediatr. 2016;114(5):441-7.

17. Coledam DHC, Ferraiol PF, Santos JW, Oliveira AR. Fatores associados à aptidão cardiorrespiratória de escolares. Rev Bras Med Esporte. 2016;22(1):21-6. https://doi.org/10.1590/1517-869220162201123568

18. Straatmann VS, Santos LAVD, Palma A, Veiga GVD. Cardiorespiratory fitness and physical activity level in adolescents. Rev Bras Cineantropom Desempenho. 2015;17(1):21-30. https://doi.org/10.5007/1980-0037.2015v17n1p21

19. Goñi IL, Arenaza L, Medrano M, García N, Cadenas-Sanchez C, Ortega FB. Associations between the adherence to the Mediterranean diet and cardiorespiratory fitness with total and central obesity in preschool children: the PREFIT project. Eur J Nutr. 2018;57(8):2975-83. https://doi.org/10.1007/s00394-017-1571-3

20. Todendi PF, Valim ARM, Reuter CP, Mello ED, Gaya AR, Burgos MS. Metabolic risk in schoolchildren is associated with low levels of cardiorespiratory fitness, obesity, and parents' nutritional profile. J Pediatr. 2016;92(4):388-93. https:// doi.org/10.1016/j.jpedp.2016.05.007

21. Eisenmann JC, Welk GJ, Ihmels M, Dollman, J. Fatness, fitness, and cardiovascular disease risk factors in children and adolescents. Med Sci Sports Exerc. 2007;39(8):1251-6. https://doi.org/10.1249/MSS.0b013e318064c8b0

22. Stoner L, Pontzer H, Gibbs BB, Moore JB, Castro N, Skidmore P, et al. Fitness and fatness are both associated with cardiometabolic risk in preadolescents. J Pediatr. 2018;217:39-45. 
23. Leal DB, Assis MAA, Conde WL, Lobo AS, Bellisle F, Andrade DF. Individual characteristics and public or private schools predict the body mass index of Brazilian children: a multilevel analysis. Cad Saúde Pública. 2018;34(5):117. https://doi.org/10.1590/0102-311X00053117

24. Vilchis-Gil J, Galván-Portillo M, Klünder-Klünder M, Cruz M, Flores-Huerta S. Food habits, physical activities and sedentary lifestyles of eutrophic and obese school children: a case-control study. Bmc Public Health. 2015;15(1):124. https://doi.org/10.1186/s12889-015-1491-1

25. Faul F, Erdfelder E, Buchner A, Lang, AG. G* Power Version 3.1. 7 [software]. Germany: Uiversität Kiel; 2013.

26. Faul F, Erdfelder E, Lang AG, Buchner A. G* Power 3: a flexible statistical power analysis program for the social, behavioral, and biomedical sciences. Behav Res Methods. 2007;39(2):175-91. https://doi.org/10.3758/BF03193146

27. Ministério da Saúde (Brasil). Orientações para avaliação de marcadores de consumo alimentar na atenção básica. Brasília: Ministério; 2015 [citado 20 set 2019]. Disponível em: https://bvsms.saude.gov.br/bvs/publicacoes/ marcadores_consumo_alimentar_atencao_basica.pdf

28. Ministério da Saúde (Brasil). Guia Alimentar para a população brasileira. 2a ed. Brasília: Ministério; 2014 [citado 20 set 2019]. Disponível em: https://bvsms.saude.gov.br/bvs/publicacoes/guia_alimentar_populacao_brasileira_2ed.pdf

29. Instituto Brasileiro de Geografia e Estatística. Pesquisa Nacional de Saúde do Escolar (PeNSE): 2015. Rio de Janeiro: Instituto; 2016 [citado 29 dez 2019]. Disponível em: https://biblioteca.ibge.gov.br/visualizacao/livros/liv97870.pdf

30. Gaya A, AR Gaya. Projeto Esporte Brasil: manual de testes e avaliação: 2016. 5a ed. Porto Alegre: Edições Perfil; 2016 [citado 28 set 2019]. Disponível em: https://www.ufrgs.br/proesp/arquivos/manual-proesp-br-2016.pdf

31. Onis MD, Onyango AW, Borghi E, Siyam A, Nishida C, Siekmann J. Development of a WHO growth reference for school-aged children and adolescents. Bulletin World Health Organization. 2007;(85):660-7.

32. Friedewald WT, Levy RI, Fredrickson DS. Estimation of the concentration of low-density lipoprotein cholesterol in plasma, without use of the preparative ultracentrifuge. Clin Chem. 1972;18(6):499-502. https://doi.org/10.1093/ clinchem/18.6.499

33. Kellar, SP, Kelvin EA. Munro's statistical methods for health care research. 6a ed. Philadelphia: Wolters Kluwer Health; 2012.

34. International Business Machines Corporation. Statistical Package for Social Sciences. version 22.0 [software]. Chicago: IBM; 2013.

35. Costa MC, Sousa AF, Lima JTN, Sousa SDF, Ferreira FV, Marques ARA. Estado nutricional, práticas alimentares e conhecimentos em nutrição de escolares. Rev Aten Saúde. 2018;16(56):12-7. https://doi.org/10.13037/ras. vol16n56.481

36. Skrede T, Aadland E, Andersen LB, Stavnsbo M, Anderssen SA, Resaland GK. Does cardiorespiratory fitness moderate the prospective association between physical activity and cardiometabolic risk factors in children? Int J Obes. 2018;42(5):1029-38. https://doi.org/10.1038/s41366-018-0108-z

37. Racette SB, Uhrich ML, White ML, Yu L, Clark, BR. Sex differences in FITNESSGRAM ${ }^{\circledast}$ health risk based on aerobic capacity and body composition among urban public elementary school children. Prev Med. 2017;103:56-9. https:// doi.org/10.1016/j.ypmed.2017.07.032

38. Nyström CD, Henriksson P, Martínez-Vizcaíno V, Medrano M, Cadenas-Sanchez C, Arias-Palencia, et al. Does cardiorespiratory fitness attenuate the adverse effects of severe/morbid obesity on cardiometabolic risk and insulin resistance in children? A pooled analysis. Diabetes Care. 2017;40(11):1580-7. https://doi.org/10.2337/dc17-1334

39. Sociedade Brasileira de Pediatria. Manual de orientação para a alimentação do lactente, do pré-escolar, do escolar, do adolescente e na escola. 3a. ed. Rio de Janeiro: Sociedade; 2012 [citado 29 dez 2019]. Disponível em: https:// www.sbp.com.br/fileadmin/user_upload/pdfs/14617a-PDManualNutrologia-Alimentacao.pdf

40. Cunha DB, Costa THM, Veiga GV, Pereira RA, Sichieri R. Ultra-processed food consumption and adiposity trajectories in a Brazilian cohort of adolescents: ELANA study. Nutr Diabetes. 2018;8(1):28. https://doi.org/10.1038/s41387018-0043-z

41. Skrede T, Stavnsbo M, Aadland E, Aadland KN, Anderssen SA, Resaland, GK, et al. Moderate-to-vigorous physical activity, but not sedentary time, predicts changes in cardiometabolic risk factors in 10-y-old children: the active smarter Kids Study. Am J Clin Nutr. 2017;105(6):1391-8. https://doi.org/10.3945/ajcn.116.150540

42. Seabra A, Katzmarzyk P, Carvalho MJ, Seabra A, Coelho-e-Silva M, Abreu S, et al. Effects of 6-month soccer and traditional physical activity programmes on body composition, cardiometabolic risk factors, inflammatory, oxidative 
stress markers and cardiorespiratory fitness in obese boys. J Sports Sci. 2016;34(19):1822-9. https://doi.org/10.108 0/02640414.2016.1140219

43. Granacher U, Borde R. Effects of sport-specific training during the early stages of long-term athlete development on physical fitness, body composition, cognitive, and academic performances. Front Physiol. 2017;8:810. https://doi. org/10.3389/fphys.2017.00810

44. Oliveira L, Braga F, Lemes V, Dias A, Brand C, Mello J, et al. Effect of an intervention in physical education classes on health related levels of physical fitness in youth. Rev Bras Ativ Fís Saúde. 2017;22(1):46-53. https://doi.org/10.12820/ rbafs.v.22n1p46-53

45. World Health Organization. World health statistics 2010. Geneva: Organization; 2010. [cited 2020 Jan 9]. Available from: https://www.who.int/whosis/whostat/2010/en/ 